
pp. 96-107.

\title{
PENGARUH MODEL PEMBELAJARAN KOOPERATIF TIPE TGT BERBASIS KEARIFAN LOKAL TRI HITA KARANA TERHADAP HASIL BELAJAR
}

\author{
${ }^{1} \mathrm{Ni}$ Komang Devi Yunita, ${ }^{2} \mathrm{Ni}$ Ketut Desia Tristiantari \\ 1,2Jurusan Pendidian Dasar, Universitas Pendidikan Ganesha, Singaraja, Indonesia \\ Singaraja, Indonesia \\ e-mail: komang.devi.yunita@undiksha.ac.id1, desiatristiantari@gmail.com3
}

\begin{abstract}
Abstrak
Penelitian ini bertujuan untuk mengetahui pergaruh hasil belajar IPA antara kelompok siswa yang dibelajarkan dengan model pembelajaran kooperatif tipe TGT berbasis Tri Hita Karana. Penelitian ini adalah penelitian eksperimen semu (Quasi Eksperimen), dengan desain penelitian non equivalent post-test only control group design. Populasi penelitian ini berjumlah 166 orang. Sampel penelitian ini adalah siswa kelas V SD Negeri 1 Banjar sebanyak 24 orang dan siswa kelas V SD Negeri 8 Banjar sebanyak 28 orang. Sampel ditentukan menggunakan teknik simple random sampling. Data hasil belajar yang diperoleh dianalisis menggunakan teknik analisis statistik deskriptif dan statistik inferensial. Berdasarkan hasil penghitungan Uji-t dengan menggunakan Independent Samples Test menunjukkan thitung $=4,246>$ ttabel $=2,00$. Selanjutnya rata - rata kelompok eksperimen yaitu 22,04 lebih besar dari rata - rata kelompok kontrol yaitu 18,75. Hal ini menunjukkan bahwa terdapat perbedaan yang signifikan pada hasil belajar IPA antara kelompok siswa yang dibelajarkan dengan model pembelajaran kooperatif tipe Team Games Tournament berbasis Tri Hita Karana dan kelompok siswa yang dibelajarkan dengan tidak menggunakan model pembelajaran kooperatif tipe Team Games Tournament berbasis Tri Hita Karana pada kelas V SD di Gugus IV Kecamatan Banjar Kabupaten Buleleng. Dengan demikian, model pembelajaran kooperatif tipe TGT berbasis Tri Hita Karana karana berpengaruh terhadap hasil belajar IPA siswa kelas V SD di Gugus IV Kecamatan Banjar Kabupaten Buleleng Tahun Pelajaran 2018/2019.
\end{abstract}

Kata-kata kunci: hasil belajar, team games tournament, tri hita karana

Abstract

This study aims to determine the differences in science learning outcomes between groups of students taught by the TGT cooperative learning model based on local wisdom Tri Hita Karana and groups of students who are taught by not using the Tri Hita Karana-based TGT cooperative learning model. This research is quasi-experimental research, with nonequivalent post-test only control group design. The population of this study amounted to 166 people. The sample of this study was the fifth-grade students of SD Negeri 1 Banjar as many as 24 people and class V students of SD Negeri 8 Banjar as many as 28 people. The sample is determined using a simple random sampling technique. Learning outcomes data obtained were analyzed using descriptive statistical analysis techniques and inferential statistics. Based on the results of the t-test calculation using Independent Samples Test shows $t$ count $=4.246>t$ table $=2.00$. Furthermore, the average experimental group of 22.04 was greater than the average control group of 18.75. This shows that there are significant differences in the learning outcomes of science between groups of students who are taught by the cooperative learning model type Team Games Tournament based on local 

pp. 96-107.

wisdom Tri Hita Karana and groups of students who are taught without using the cooperative learning model of Team Games Tournament based on tri local wisdom. Tri Hita Karana in class V elementary school in Cluster IV District of Banjar, Buleleng Regency. Thus, the TGT cooperative learning model based on local wisdom Tri Hita Karana has a positive effect on the science learning outcomes of fifth-grade elementary school students in Cluster IV of Banjar District, Buleleng Regency, Academic Year 2018/2019.

Keywords : learning outcomes, team games tournament, tri hita karana

\section{PENDAHULUAN}

Pembelajaran merupakan suatu proses untuk membelajarkan seseorang tentang suatu informasi atau konsep melalui pengalaman. Slavin (dalam Listyarini) mengemukakan bahwa pembelajaran merupakan proses perubahan tingkah laku seseorang melalui pengalaman. Dengan kata lain pembelajaran merupakan bantuan yang diberikan pendidik agar terjadi proses pemerolehan ilmu dan pengetahuan, penguasaan, kemahiran, dan tabiat, serta pembentukan sikap dan keyakinan pada peserta didik (Susanto, 2013: 19 ). Peran guru dalam proses pembelajaran sangatlah penting, dimana guru harus mampu untuk menerapkan pembelajaran yang dapat membuat siswa merasa nyaman dalam proses belajarnya. Guru harus pandai dalam merancang proses pembelajaran agar menarik perhatian siswa untuk tertarik dalam mengikuti proses pembelajaran. Salah satu masalah yang dihadapi dunia pendidikan saat ini adalah masalah lemahnya pelaksanaan proses pembelajaran yang diterapkan para guru di sekolah. Proses pembelajaran yang terjadi selama ini kurang mampu mengembangkan kemampuan berpikir peserta didik. Kondisi ini juga menimpa pada pembelajaran IImu Pengetahuan Alam (IPA), yang memperlihatkan bahwa selama ini proses pembelajaran sains di sekolah dasar masih banyak dilaksanakan secara konvensional. Sains atau IPA adalah usaha manusia dalam memahami alam semesta melalui pengamatan yang tepat pada sasaran. IPA merupakan ilmu yang mempelajari tentang alam. IPA merupakan salah satu mata pelajaran yang harus dikuasai oleh siswa secara optimal mengingat muatan materi IPA merupakan salah satu disiplin ilmu yang paling mendominasi dalam setiap pembelajaran.

Berdasarkan pengertian IPA tersebut tujuan pembelajaran sains (IPA) di sekolah dasar salah satunya mengembangkan rasa ingin tahu, sikap positif dan kesadaran tentang adanya hubungan yang saling memengaruhi antara IPA, lingkungan, teknologi, dan masyarakat serta meningkatkan kesadaran untuk menghargai alam dan segala keteraturannya sebagai salah satu ciptaan Tuhan. Sejalan dengan tujuan pendidikan IPA di atas, bahwa secara tidak langsung di dalam IPA peserta didik diajarkan mengenai nilai - nilai agama salah satunya menghargai alam dan segala isinya sebagai ciptaan Tuhan agar nantinya tercipta suatu hubungan yang harmonis antara semua makhluk dengan penciptaNya. Konsep hubungan yang harmonis antara semua makhluk dengan penciptaNya sudah tidak asing lagi dikenal khususnya bagi masyarakat di Bali. Konsep ini dikenal dengan nama "Tri Hita Karana". Tri Hita Karana merupakan salah satu budaya lokal yang terdapat di Bali,yang mengemukakan tentang hubungan baik manusia dengan Tuhan, sesama manusia, dan lingkungan tempat tinggalnya. Tri Hita Karana merupakan suatu hubungan atau kehidupan yang harmonis dan seimbang antara bhakti/percaya kepada Tuhan Yang Maha Esa, mengabdikan diri kepada sesama Manusia (sosial) dan menyayangi alam lingkungan berdasarkan konsep yadnya. Dalam pembelajaran IPA guru tidak cukup terfokus pada satu model saja tetapi guru perlu mencoba menerapkan model-model 

pp. 96-107.

pembelajaran inovatif yang sesuai dengan materi pembelajaran khususnya IPA adalah mata pelajaran yang digunakan sebagai wahana untuk membentuk kepribadian anak secara keseluruhan. Selain itu perlu adanya penanaman budaya lokal pada diri anak sejak dini salah satunya mengenalkan konsep Tri Hita Karana, yang nantinya dapat diwujudkan dalam kehidupan sehari-hari baik sebagai individu maupun sebagai anggota masyarakat.

Berdasarkan hasil observasi yang telah dilakukan pada tanggal 9 Januari 2019 di SD gugus IV Kecamatan Banjar, ditemukan permasalahan diantaranya: diperoleh hasil sebagai berikut 1) masih banyak guru tidak melakukan kegiatan pembelajaran dengan memfokuskan pada pengembangan keterampilan proses sains anak sehingga pembelajaran yang dilakukan hanya berpusat pada penyampaian materi dalam buku teks saja. Keterampilan proses sains yang dimaksud adalah keterampilan yang dilakukan oleh para ilmuwan, seperti mengamati, mengukur, mengklasifikasikan, dan menyimpulkan. 2) Masih menerapkan pembelajaran konvensional. Keadaan yang seperti inilah yang mendorong siswa untuk menghafal pada setiap diadakan tes dan ulangan, hal inilah yang mengakibatkan siswa menjadi tertekan dan pembelajaran yang dilaksanakan tidak bermakna bagi siswa. Hal tersebut disebabkan kurangnya pemahaman siswa terhadap materi yang telah diajarkan oleh guru sehingga siswa merasa enggan untuk berbicara.

Permasalahan-permasalahan di atas diperkuat dengan hasil wawancara yang dilakukan dengan guru kelas V SD di Gugus IV Kecamatan Banjar pada tanggal 12 - 13 Januari 2019 guru menyampaikan bahwa 1) dalam proses pembelajaran IPA guru lebih banyak ceramah sehingga siswa kurang aktif dan cepat merasa bosan. 2) Guru hanya pernah menerapkan satu model saja yaitu model pembelajaran Jigsaw, tanpa pernah menerapkannya lagi. 3) Hasil belajar IPA siswa masih rendah karena siswa belajar hanya terpaku pada buku dan guru. 4) Siswa kurang termotivasi untuk belajar dan menganggap mata pelajaran IPA adalah mata pelajaran yang kurang menarik.

Selain hasil observasi dan wawancara, diperkuat juga dengan hasil pencatatan dokumen hasil UTS IPA siswa kelas V di SD Gugus IV Kecamatan Banjar, dengan rata-rata hasil belajar yang masih tergolong rendah. Dapat dilihat pada tabel 1 berikut ini.

Tabel 1. Rata-rata nilai UTS IPA Siswa Kelas V di Gugus IV Kecamatan Banjar.

Tabel 1. Rata-rata nilai UTS IPA Siswa Kelas V di Gugus IV Kecamatan Banjar.

\begin{tabular}{llccccccc}
\hline No & Sekolah & $\begin{array}{c}\text { Jumlah } \\
\text { Siswa }\end{array}$ & $\begin{array}{c}\text { Rata - } \\
\text { rata } \\
\text { nilai } \\
\text { UTS }\end{array}$ & KKM & \multicolumn{2}{c}{$\begin{array}{c}\text { Siswa yang } \\
\text { mencapai KKM }\end{array}$} & \multicolumn{2}{c}{$\begin{array}{c}\text { Siswa yang tidak } \\
\text { mencapai KKM }\end{array}$} \\
\hline 1 & SDN 1 Banjar & 24 & 61,04 & 65 & 8 & 33,33 & 16 & 66,67 \\
2 & SDN 3 Banjar & 15 & 59,80 & 60 & 10 & 66,7 & 5 & 33,33 \\
3 & SDN 5 Banjar & 17 & 58,35 & 65 & 7 & 41,18 & 10 & 58,82 \\
4 & SDN 6 Banjar & 12 & 57,25 & 60 & 7 & 58,33 & 5 & 41,67 \\
5 & SDN 7 Banjar & 24 & 55,67 & 60 & 4 & 16,67 & 20 & 83,33 \\
6 & SDN 8 Banjar & 28 & 60,32 & 62 & 20 & 71,43 & 8 & 28,57 \\
7 & SDN 9 Banjar & 35 & 56,86 & 60 & 21 & 60 & 14 & 40 \\
8 & SDN 10 Banjar & 11 & 55,18 & 60 & 5 & 45,45 & 6 & 54,55 \\
& Rata - rata & & 57,96 & 61,5 & 10,25 & 49,14 & 10,5 & 50,87 \\
\hline
\end{tabular}

(Sumber: Tata Usaha SD di Gugus IV Kecamatan Banjar, 2018). 

pp. 96-107.

Berdasarkan tabel tersebut, tampak bahwa rata-rata nilai siswa kelas $\mathrm{V}$ masih berada di bawah KKM. Dengan presentase siswa yang mencapai KKM sebanyak 49,14\% dan sebanyak 50,87\% siswa yang tidak mencapai KKM. Ini artinya masih banyak siswa yang berada di bawah KKM, sehingga perlu adanya suatu usaha untuk memperbaiki kendala tersebut. Untuk mengatasi permasalahan tersebut, diperlukan inovasi dari guru untuk mengemas pembelajaran IPA agar pembelajaran IPA dapat digemari oleh siswa. Salah satu inovasi model pembelajaran yang dapat digunakan agar siswa dapat ikut terlibat aktif dalam proses pembelajaran, sehingga berdampak pada peningkatan hasil belajar IPA siswa kelas V SD di gugus IV Kecamatan Banjar adalah menggunakan model pembelajaran kooperatif tipe Team Games Tournament Berbasis Tri Hita Karana.

Model pembelajaran diartikan sebagai prosedur sistematis dalam mengorganisasikan pengalaman belajar untuk mencapai tujuan belajar. Dalam model pembelajaran kooperatif, guru lebih berperan sebagai fasilitator yang berfungsi sebagai jembatan penghubung kearah pemahaman yang lebih tinggi, dengan catatan siswa sendiri. Guru tidak hanya memberikan pengetahuan, tetapi juga harus membangun pengetahuan dalam pikiran siswanya. Pembelajaran kooperatif (cooperative learning) merupakan model pembelajaran dengan cara siswa belajar dan bekerja dalam kelompok-kelompok kecil secara kolaboratif yang anggotanya terdiri dari empat hingga lima orang siswa dengan struktur kelompok bersifat heterogen. Kelough \& Kelough (dalam Nurdyansyah 2016: 52) menyatakan bahwa model pembelajaran kooperatif merupakan suatu strategi pembelajaran secara berkelompok, siswa belajar bersama dan saling membantu dalam menyelesaikan tugas dengan penekanan pada saling support di antara anggota kelompok, karena keberhasilan belajar siswa tergantung pada keberhasilan kelompoknya.

Salah satu model pembelajaran yang dapat digunakan agar siswa ikut terlibat aktif dalam proses pembelajaran adalah model pembelajaran Team Game Tournament (TGT). TGT adalah salah satu tipe atau model pembelajaran kooperatif yang mudah diterapkan, melibatkan aktivitas seluruh siswa tanpa harus ada perbedaan status, melibatkan peran siswa sebagai tutor sebaya dan mengandung unsur permainan serta reinforcement. Dalam model pembelajaran kooperatif tipe TGT siswa dibentuk dalam kelompok-kelompok kecil yang terdiri 5 sampai 6 siswa yang heterogen, baik dalam prestasi akademik, jenis kelamin, ras, maupun etnis. Komponen-komponen dalam TGT adalah penyajian materi, tim, game, turnamen, dan penghargaan kelompok. Aktivitas belajar dengan permainan yang dirancang dalam pembelajaran kooperatif model TGT memungkinkan siswa dapat belajar lebih rilaks di samping menumbuhkan tanggung jawab, kerja sama, persaingan sehat, dan keterlibatan belajar

(Komalasari, 2013:67). Model Teams Games Tournament memiliki fungsi, yaitu menuntut keseriusan siswa dalam mengikuti pembelajaran dan memahami secara seksama penjelasan guru, menuntut siswa untuk berkontribusi langsung dalam pembelajaran, melatih siswa untuk berkompetisi secara sehat, bersama kelompok, siswa dilatih untuk memupuk kerja sama tanggung jawab, dan tenggang rasa, dan pemberian penghargaan akan menumbuhkan motivasi serta semangat belajar siswa (Rosidah, 2013). Model pembelajaran kooperatif tipe TGT siswa dituntut untuk lebih aktif dan kreatif, adanya interaksi dan kerjasama yang baik antara siswa dengan siswa dan siswa dengan guru. Siswa yang memiliki kemampuan lebih aktif membantu temannya dalam memecahkan masalah yang dihadapi, sehingga siswa yang memiliki kemampuan rendah termotivasi untuk lebih aktif dalam belajar (Darmawati, 2016).

Perpaduan antara model pembelajaran kooperatif tipe TGT berbasis kearifan lokal tri hita karana terlihat pada saat pembelajaran berlangsung. Implementasi tri hita karana unsur 

pp. 96-107.

parhyangan terlihat pada saat guru dan siswa melaksanakan persembahyangan atau berdoa saat mengawali dan mengakhiri pembelajaran. Sedangkan implementasi unsur pawongan terlihat pada saat proses pembelajaran yaitu pada saat siswa berdiskusi dengan kelompoknya dan melaksanakan tanya jawab dengan guru serta siswa lainnya. Selanjutnya, implementasi unsur palemahan terlihat pada saat guru dan siswa melaksanakan pembersihan lingkungan kelas saat mengawali dan mengakhiri pembelajaran. Dengan penggunaan model pembelajaran kooperatif tipe TGT berbasis Tri Hita Karana ini diharapkan budaya lokal yang terdapat di Bali hendaknya ditanamkan sejak dini. Perlunya penanaman budaya lokal sejak dini dilakukan karena seseorang sangat mudah dibentuk kepribadiannya dari sejak dini agar budaya lokal yang telah ada tidak dilupakan begitu saja.

\section{METODE}

Jenis penelitian ini adalah penelitian eksperimen semu (Quasi Eksperiment). Desain penelitian ini menggunakan Non Equivalent Post-test Only Control Group Design. Desain ini menggunakan 2 kelompok yaitu kelas eksperimen dan kelas kontrol. Kelas eksperimen adalah kelompok yang diberikan perlakuan dengan menerapakan model pembelajaran kooperatif tipe Team Games Tournament, sedangkan kelompok kelas kontrol adalah kelompok pengendali yaitu kelas yang tidak mendapat perlakuan. Populasi dalam penelitian ini adalah seluruh siswa kelas V SD di Gugus IV Kecamatan Banjar Kabupaten Buleleng yang berjumlah 166 orang siswa.

Teknik pemilihan sampel dalam penelitian ini adalah simple random sampling, yaitu pengambilan sampel anggota populasi secara acak tanpa memperhatikan strata yang ada. Dari hasil random yang dilakukan tersebut, SD yang terpilih adalah SD Negeri 8 Banjar dan SD Negeri 1 Banjar. Sampel yang ditetapkan dalam penelitian ini adalah siswa kelas V SD Negeri 8 Banjar yang berjumlah 28 siswa dan kelas V SD Negeri 1 Banjar berjumlah 24 siswa. Total seluruh sampel adalah 52 siswa.

Metode yang digunakan untuk mengumpulkan data dalam penelitian ini adalah dengan menggunakan tes untuk hasil belajar aspek kognitif. Tes yang digunakan adalah tes hasil belajar IPA berupa tes pilihan ganda. Tes tersebut terdiri dari 30 butir soal. Soal yang digunakan untuk post-test sebelumnya telah di uji judges, kemudian diuji cobakan. Uji coba tes hasil belajar IPA meliputi, uji validitas butir, uji reliabilitas tes, uji daya beda dan uji tingkat kesukaran. Penelitian ini menggunakan dua metode analisis data yaitu metode analisis statistik deskriptif dan statistik inferensial. Metode analisis data yang digunakan untuk menguji hipotesis dalam penelitian ini adalah Uji-t dengan menggunakan Independent Samples Test berbantuan SPSS-17.0 for windows. Sebelum dilakukan uji hipotesis dengan metode statistika tersebut, terlebih dahulu dilakukan uji prasyarat analisis yang meliputi uji normalitas sebaran data dengan menggunakan bantuan SPSS-17.0 for windows uji statistik Kolmogorov-Smirnov pada taraf signifikan 0,05 dan uji homogenitas varians dengan menggunakan bantuan SPSS-17.0 for windows pada taraf signifikan 0,05.

\section{HASIL DAN PEMBAHASAN}

Dari hasil penelitian terhadap 28 orang siswa yang dibelajarkan dengan model pembelajaran kooperatif tipe Team Games Tournament berbasis Tri Hita Karana diperoleh skor tertinggi adalah 30 dan skor terendah adalah 13. Untuk mempermudah dalam mendeskripsikan data hasil post test IPA pada kelompok eksperimen terlebih dahulu data tersebut harus disajikan ke dalam tabel distribusi frekuensi. 
Ni Komang Devi Yunita, ${ }^{2}$ Ni Ketut Desia Tristiantari. (2018). Jurnal Pendidikan Multikultural Indonesia. Vol. 1 (2) pp. 96-107.

Data yang disajikan ke dalam tabel distribusi frekuensi terlebih dahulu harus ditentukan banyak kelas, rentangan (range), dan panjang kelas interval. Berdasarkan hasil penghitungan, maka ditetapkan banyak kelas adalah 6 dan panjang kelas adalah 3 . Distribusi frekuensi data hasil belajar IPA kelompok eksperimen disajikan pada Tabel 2.

Tabel 2. Distribusi Frekuensi Data Hasil Post- test Kelompok Eksperimen Tabel 2. Distribusi Frekuensi Data Hasil Post- test Kelompok Eksperimen

\begin{tabular}{ccccc}
\hline No & Interval & Titik Tengah & $\begin{array}{c}\text { Frekuensi } \\
\text { Absolut (f) }\end{array}$ & $\begin{array}{c}\text { Frekuensi } \\
\text { Komulatif }\end{array}$ \\
\hline 1 & $13-15$ & 14 & 1 & 14 \\
2 & $16-18$ & 17 & 3 & 51 \\
3 & $19-21$ & 18 & 7 & 140 \\
4 & $22-24$ & 23 & 11 & 253 \\
5 & $25-27$ & 26 & 5 & 130 \\
6 & $28-30$ & 29 & 1 & 29 \\
& Jumlah & & 28 & \\
\hline
\end{tabular}

Berdasarkan tabel distribusi frekuensi yang telah dibuat, maka dapat dilakukan penghitungan mean (M), median (Me), modus (Mo), standar deviasi (SD) dan varians (S2). Setelah dilakukan penghitungan skor mean (M) yaitu 22,04 skor median (Me) yaitu 24,17, skor modus (Mo) yaitu 23,30, standar deviasi (SD) yaitu 3,31 dan varians (S2) yaitu 10,98. Data hasil Post-test kelompok eksperimen kemudian disajikan ke dalam grafik polygon seperti pada gambar 1.

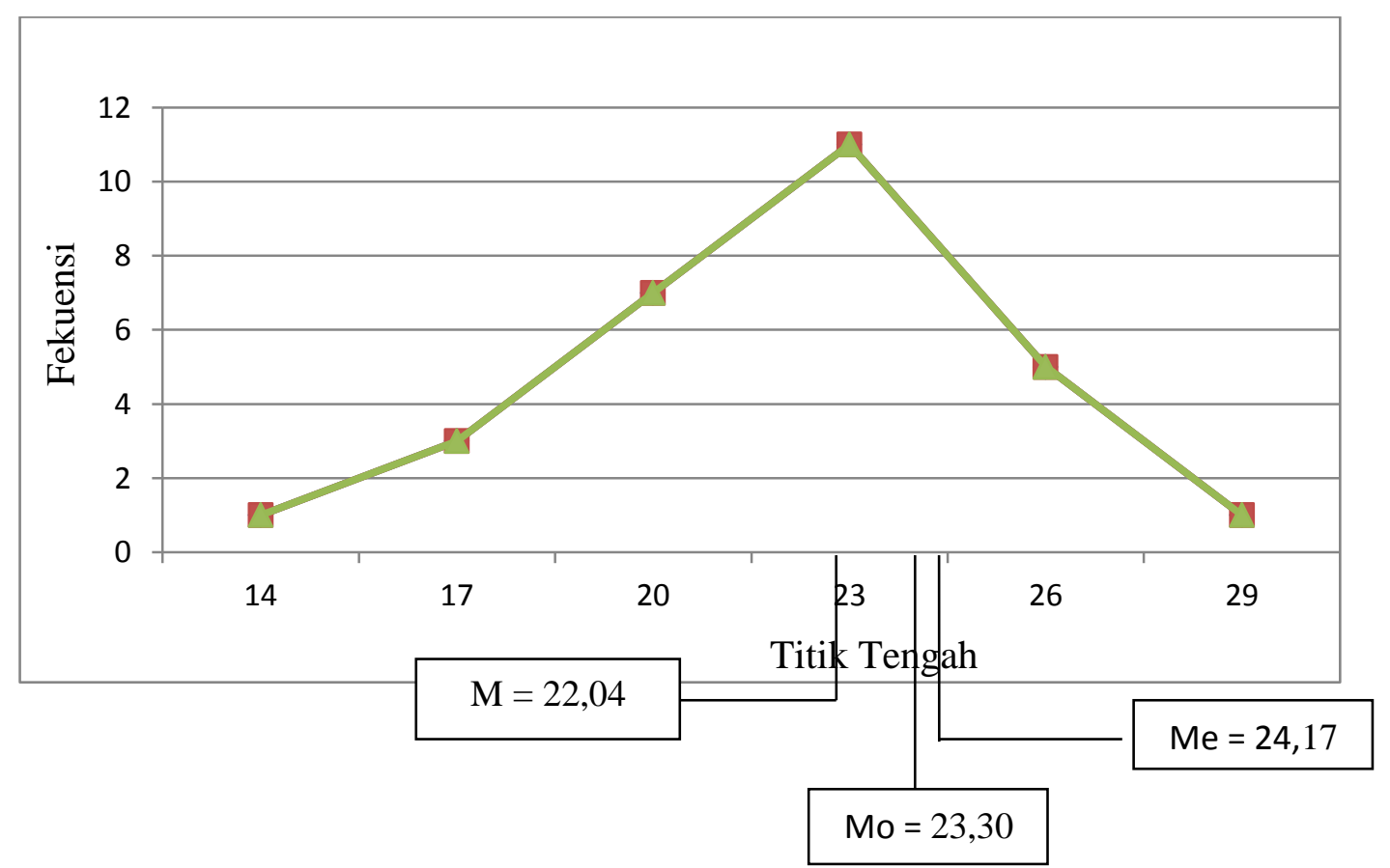

Gambar 1. Kurva Polygon Data Post -test Kelompok Esperimen

Berdasarkan kurva polygon tersebut diketahui bahwa sebagian besar skor hasil belajar IPA kelompok siswa yang dibelajarkan dengan menggunakan model pembelajaran kooperatif tipe Team Games Tournament berbasis Tri Hita Karana cenderung tinggi dapat diketahui nilai $\mathrm{Mo}>\mathrm{Me}>\mathrm{M}(23,30>24,17>22,04)$. 
Ni Komang Devi Yunita, ${ }^{2}$ Ni Ketut Desia Tristiantari. (2018). Jurnal Pendidikan Multikultural Indonesia. Vol. 1 (2) pp. 96-107.

Untuk mengetahui kualitas dari variabel hasil belajar IPA siswa, skor rata-rata hasil belajar IPA siswa dikonversikan dengan menggunakan kriteria rata-rata ideal (MI) dan standar deviasi ideal (SDi) sehingga di dapatkan skor rata-rata hasil belajar siswa kelompok eksperimen adalah 22,04. Berdasarkan hasil konversi, dapat dinyatakan bahwa rata-rata hasil belajar IPA kelompok eksperimen termasuk dalam kategori sangat tinggi.

Selanjutnya, dari hasil penelitian dari 24 orang siswa yang dibelajarkan tanpa menggunakan model pembelajaran kooperatif tipe Team Games Tournament berbasis Tri Hita Karana diperoleh skor tertinggi adalah 28 dan skor terendah adalah 11. Untuk mempermudah dalam mendeskripsikan data hasil post test hasil belajar IPA pada kelompok kontrol terlebih dahulu data tersebut harus disajikan ke dalam tabel distribusi frekuensi. Data yang disajikan ke dalam tabel distribusi frekuensi terlebih dahulu harus ditentukan banyak kelas, rentangan (range), dan panjang kelas interval.

Berdasarkan hasil penghitungan, maka ditetapkan banyak kelas adalah 6 dan panjang kelas adalah 3. Distribusi frekuensi data hasil belajar IPA kelompok kontrol disajikan pada tabel 3.

Tabel 3 . Distribusi Frekuensi Data Hasil Post- test Kelompok Kontrol

\begin{tabular}{ccccc}
\hline No & Interval & Titik Tengah & $\begin{array}{c}\text { Frekuensi Absolut } \\
(\mathbf{f})\end{array}$ & $\begin{array}{c}\text { Frekuensi } \\
\text { Komulatif }\end{array}$ \\
\hline 1 & $11-13$ & 12 & 1 & 24 \\
2 & $14-16$ & 15 & 3 & 23 \\
3 & $17-19$ & 18 & 14 & 19 \\
4 & $20-22$ & 21 & 2 & 6 \\
5 & $23-25$ & 24 & 3 & 4 \\
6 & $26-28$ & 27 & 1 & 1 \\
& Jumlah & & 24 & \\
\hline
\end{tabular}

Berdasarkan tabel distribusi frekuensi diatas maka dapat dilakukan perhitungan mean (M), median (Me), modus (Mo), standar deviasi (SD) dan varians (S2). Setelah dilakukan perhitungan skor mean (M) yaitu 18,75 skor median (Me) yaitu 18,59, skor modus (Mo) yaitu 18,07, standar deviasi (SD) yaitu 327 dan varians (S2) yaitu 10,71. Data hasil Post-test kelompok kontrol kemudian disajikan ke dalam grafik polygon seperti pada gambar 2 .

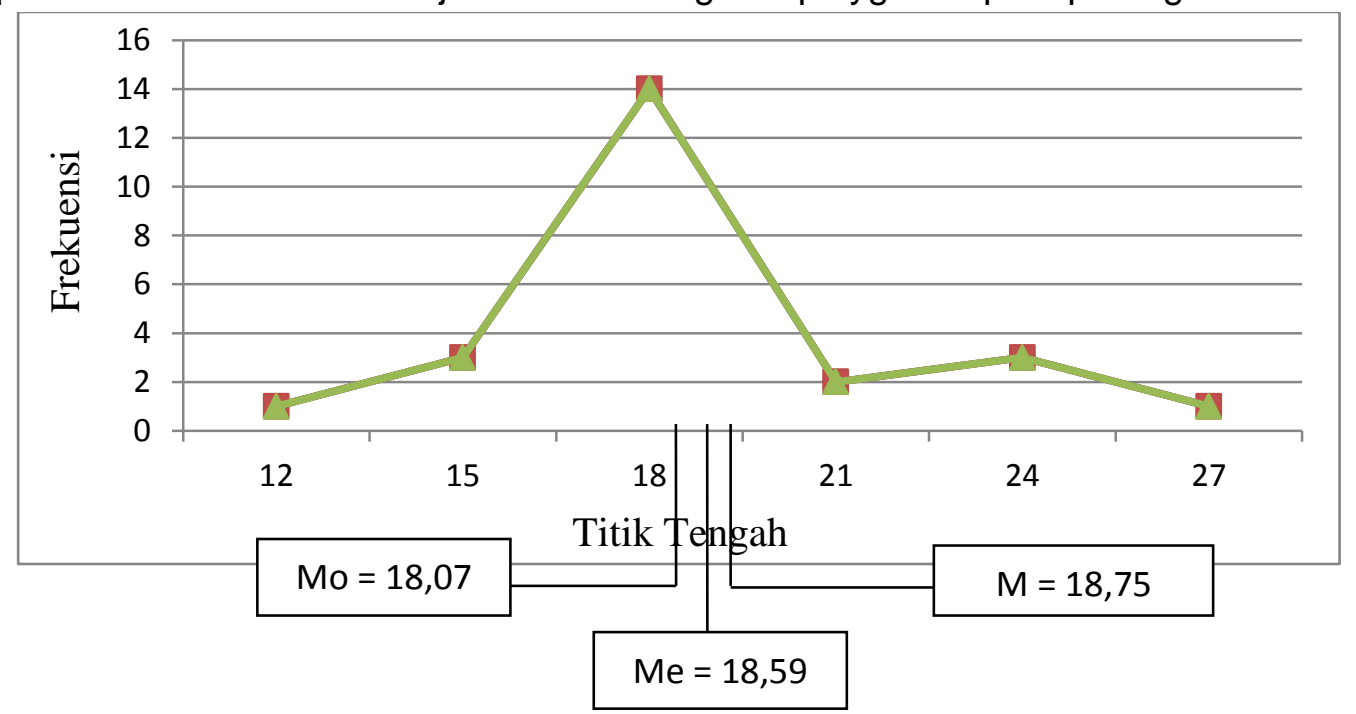

Gambar 2 Kurva Polygon Data Post -test Kelompok Kontrol 

pp. 96-107.

Berdasarkan kurva polygon tersebut diketahui bahwa sebagian besar skor hasil belajar IPA kontrol cenderung rendah daripada skor hasil belajar IPA kelompok eksperimen dengan nilai $\mathrm{Mo}<\mathrm{Me}<\mathrm{M}(18,07>18,59>18,75)$.

Untuk mengetahui kualitas dari variabel hasil belajar IPA siswa, skor rata-rata hasil belajar IPA siswa dikonversikan dengan menggunakan kriteria rata-rata ideal (MI) dan standar deviasi ideal (SDi) sehingga di dapatkan skor rata-rata hasil belajar siswa kelompok kontrol adalah 18,75. Berdasarkan hasil konversi, dapat dinyatakan bahwa rata-rata hasil belajar IPA kelompok kontrol termasuk dalam kategori tinggi.

Tabel 4. Uji Normalitas Posttest Kelompok Eksperimen dan Kontrol

\begin{tabular}{l|c|c|c|c|c|c}
\hline & \multicolumn{3}{|c|}{ Kolmogorov-Smirnov $^{\mathrm{a}}$} & \multicolumn{3}{c}{ Shapiro-Wilk } \\
\cline { 2 - 9 } & Statistic & Df & Sig. & Statistic & Df & Sig. \\
\hline Kelompok eksperimen & .163 & 24 & .098 & .962 & 24 & .473 \\
Kelompok kontrol & .174 & 24 & .059 & .931 & 24 & .103 \\
\hline
\end{tabular}

a. Lilliefors Significance Correction

Berdasarkan data pada tabel di atas, menujukkan bahwa angka statistik KolmogorovSmirnov pada Posttest eksperimen dan kontrol adalah 0.098 dan 0,059, ini berarti angka signifikan lebih besar dari 0,05. Maka dapat disimpulkan semua sebaran data posttest sudah berdistribusi normal.

Tabel 5. Hasil Uji Homogenitas Varians

Test of Homogeneity of Variance

\begin{tabular}{ll|c|c|c|c}
\hline & & Levene Statistic & df1 & df2 & Sig. \\
\hline $\begin{array}{l}\text { posttest eksperimen } \\
\text { dan kontrol }\end{array}$ & Based on Mean & .591 & 1 & 50 & .446 \\
& Based on Median & .618 & 1 & 50 & .435 \\
& $\begin{array}{l}\text { Based on Median and with } \\
\text { adjusted df } \\
\end{array}$ & .618 & 1 & 49.949 & .435 \\
& Based on trimmed mean & & & & .457 \\
\hline
\end{tabular}

Uji homogenitas varians dilakukan untuk menguji perbedaan yang terjadi pada kedua kelompok antara kelompok eksperimen dan kelompok kontrol benar - benar berasal dari perbedaan perlakuan yang diberikan, bukan akibat dari perbedaan yang terjadi dalam kelompok. Berdasarkan data pada tabel di atas, nilai signifikan pada kolom Based on Mean sebesar 0,446. Hasil ini menunjukkan harga sidnifikan tersebut lebih besar dari 0,05, sehingga data hasil penelitian Posstest pada kelompok eksperimen dan kontrol dinyatakan homogen. Rangkuman hasil uji homogenitas disajikan pada tabel

Pengujian hipotesis penelitian dilakukan Uji-t dengan menggunakan Independent Samples Test berbantuan SPSS-17.0 for windows. Kriteria pengujian hipotesis yang 
Ni Komang Devi Yunita, ${ }^{2}$ Ni Ketut Desia Tristiantari. (2018). Jurnal Pendidikan Multikultural Indonesia. Vol. 1 (2) pp. 96-107.

digunakan adalah $\mathrm{HO}$ diterima jika $t$ hitung lebih kecil atau sama dengan $t$ tabel (thitung $\leq$ ttabel), dan $\mathrm{HO}$ ditolak jika harga t hitung lebih besar dari t tabel (thitung $>$ ttabel). Hasil Uji-t dengan menggunakan Independent Samples Test berbantuan SPSS-17.0 for windows disajikan pada tabel 6.

Tabel 6. Rangkuman Hasil Uji-t Sampel Independent

Independent Samples Test



Berdasarkan hasil perhitungan menggunakan uji-t sampel independent dengan rumus polled varians diperoleh thitung adalah 4,246 dan ttabel pada taraf signifikansi $5 \%$ dan db $(28+24-2)=50$ adalah 2,00. Hal ini berarti, thitung lebih besar dari ttabel (thitung $>$ ttabel), sehingga $\mathrm{H} 0$ ditolak dan $\mathrm{H} 1$ di terima. Berdasarkan analisis tersebut, dapat diintrepretasikan bahwa terdapat perbedaan yang signifikan hasil belajar IPA antara siswa yang belajar dengan model pembelajaran koopeatif tipe Team Games Tournament berbasis Tri Hita Karana dengan siswa yang dibelajarkan dengan tidak menggunakan model pembelajaran model pembelajaran koopeatif tipe Team Games Tournament berbasis Tri Hita Karana pada siswa kelas V Sekolah Dasar di Gugus IV Kecamatan Banjar Kabupaten Buleleng tahun Pelajaran 2018/2019.

Berdasarkan penelitian yang telah dilakukan pada kelompok eksperimen dan kelompok kontrol terdapat beberapa hal yang ditemukan diantaranya sebagai berikut.

Pertama, setelah dilakukan analisis data terdapat perbedaan yang signifikan hasil belajar IPA antara siswa yang dibelajarkan dengan menggunakan model pembelajaran kooperatif tipe Team Games Tournament berbasis Tri Hita Karana lebih baik dibandingkan dengan kelompok yang dibelajarkan dengan tidak menggunakan model pembelajaran kooperatif tipe Team Games Tournament berbasis kearifan lokal tri hita karana. Hal ini ditunjukkan dari nilai rata - rata kelompok eksperimen adalah 22.04 lebih besar dari nilai rata - rata kelompok kontrol adalah 18.75. Hasil belajar siswa tergolong tinggi pada kelompok eksperimen dengan menggunakan model pembelajaran kooperatif tipe Team 

pp. 96-107.

Games Tournament berbasis Tri Hita Karana. Secara deskriptif, hasil belajar siswa pada kelompok eksperimen lebih tinggi dibandingkan dengan hasil belajar pada kelompok kontrol. Hal ini disebabkan oleh kegiatan pembelajaran pada model kooperatif tipe Team Games Tournament memberikan pengalaman belajar kepada siswa dalam mengkonstruksi dan mengembangkan pengetahuan yang dimiliki siswa. Dalam pengalaman belajar ini, peserta didik diberikan kesempatan membangun sendiri pengetahuan mereka lewat keterlibatan dalam proses belajar mengajar.

Penanaman konsep Tri Hita Karana sudah berjalan sesuai dengan yang diharapkan pada unsur parhyangan siswa menjadi terbiasa dan khusuk berdoa sebelum dan setelah proses pembelajaran. Pada unsur pawongan siswa yang pada awalnya jarang mau berinteraksi dengan teman lainnya, menjadi pribadi yang supel dan perlahan mau berinteraksi serta saling menghargai perbedaan pendapat dengan temanya. Pada unsur palemahan siswa menjadi lebih perduli akan pentingnya menjaga kebersihan lingkungan sekitar. Perubahan sikap ini terjadi karena di dalam proses pembelajaran yang dilakukan selalu ditanamkan mengenai konsep Tri Hita Karana, mulai dari sebelum masuk kelas siswa diajarkan untuk membersihkan kelas (palemahan), selanjutnya sebelum dan setelah melaksanakan pembelajaran siswa diajak untuk berdoa (parhyangan), kemudian siswa diberi kesempatan untuk menyampaikan pendapat dan bekerjasama dengan kelompoknya dalam menyelesaikan masalah (pawongan). Berdasarkan temuan di atas, dapat diketahui bahwa ketiga unsur yang terdapat pada konsep Tri Hita Karana telah terlaksana dengan baik sehingga terciptanya suatu hubungan yang harmonis. Ketiga, siswa menjadi bersemangat dalam mengikuti pembelajaran karena pembelajaran yang dilaksanakan menyenangkan bagi siswa. Hal ini disebabkan oleh lima tahap yang terdapat pada model pembelajaran kooperatif tipe Team Games Tournament . Model pembelajaran pembelajaran kooperatif tipe Team Games Tournament. memiliki 5 tahap menurut Mulyatiningsih (2012: 244-245) yaitu penyajian kelas (class presentation,), Belajar dalam kelompok (Team), Permainan (Game), Pertandingan atau lomba (Tournament), Penghargaan kelompok (Team recognition).

Dalam proses pembelajaran siswa diberikan kesempatan mengungkapkan ide, gagasan yang dimilikinya serta kebebasan bekerjasama dalam kelompok kecil dengan saling mengungkapkan pendapatnya masing - masing untuk menyelesaikan masalah yang terdapat pada LKS. Hal ini tidak akan membuat siswa menjadi tertekan, sehingga pembelajaran yang dilaksanakan menjadi menyenangkan bagi siswa. Selain itu, selama kegiatan pembelajaran siswa lebih aktif karena kegiatan pembelajaran menggunakan model pembelajaran kooperatif tipe Team Games Tournament ini melibatkan siswa secara langsung dalam proses pembelajaran. Hasil penelitian Handayana (2014) dalam penelitiannya menunjukkan bahwa penerapan model pembelajaran kooperatif tipe TGT yang dikumpulkan dari tes hasil belajar IPA menunjukkan bahwa hasil belajar IPA siswa lebih baik. Hal ini disebabkan karena penerapan model pembelajaraan kooperatif tipe TGT membuat siswa lebih aktif dalam proses belajar mengajar di kelas. Dengan mempelajari bersama-sama, mendiskusikan, menemukan dan menghayati sendiri konsep-konsep penting yang terkandung dalam materi yang dibahas, serta mempertandingkan semua pengetahuan yang telah diperoleh dalam kelompok mereka masing-masing. Demikian pula penelitian yang dilakukan oleh Wulandari, dalam penelitiannya menunjukkan bahwa penerapan model pembelajaran kooperatif tipe TGT dapat meningkatkan hasil belajar siswa. Peningkatan hasil belajar ini disebabkan karena penerapan model pembelajaraan kooperatif tipe TGT membuat siswa aktif dalam pembelajaran dan pemahaman siswa terhadap konsep yang dipelajari. 
Ni Komang Devi Yunita, ${ }^{2}$ Ni Ketut Desia Tristiantari. (2018). Jurnal Pendidikan Multikultural Indonesia. Vol. 1 (2) pp. 96-107.

\section{SIMPULAN}

Adapun simpulan yang dapat dikemukakan dari penelitian ini yaitu terdapat pengaruh yang signifikan pembelajaran berpendekatan saintifik berorientasi Tri Hita Karana terhadap kompetensi pengetahuan IPS siswa kelas IV SD Kecamatan Bangli Kabupaten Bangli. Hasil pengujian hipotesis membuktikan bahwa thitung $>$ ttabel $(43,44>1,68023)$ yang diuji pada taraf signifikan $5 \%$ dengan $\mathrm{db}=43$. Dengan demikian, pendekatan saintifik berorientasi $T r i$ Hita Karana berpengaruh terhadap kompetensi pengetahuan IPS siswa kelas IV SD gugus II Kecamatan Bangli Kabupaten Bangli.

Berdasarkan hasil penelitian yang telah dilakukan, saran yang dapat disampaikan adalah yang pertama, siswa disarankan agar lebih aktif dan semangat dalam mengikuti pembelajaran yang diberikan guru, sehingga dapat meningkatkan kompetensi pengetahuan di setiap mata pelajaran. Kedua, engan dilaksanakannya penelitian ini, guru disarankan agar lebih berinovasi dan kreatif untuk memberikan fasilitas seperti sumber belajar ataupun media pembelajaran. Ketiga, hasil penelitian ini agar dapat digunakan oleh kepala sekolah sebagai acuan untuk membimbing guru-guru dalam melaksanakan pembelajaran dengan mengembangkan pendekatan saintifik seperti mengorientasikannya dengan Tri Hita Karana untuk meningkatkan kompetensi pengetahuan siswa. Keempat, dengan dilakukannya penelitian ini, kepada peneliti lain disarankan agar dapat digunakan sebagai acuan keputusan untuk melakukan penelitian dalam variabel yang sama ataupun variabel yang berbeda. Sebelum melaksanakan penelitian sebaiknya diadakan pre-test terlebih dahulu, agar perbedaan hasil belajar siswa lebih jelas terlihat.

\section{DAFTAR PUSTAKA}

Adiwiguna, I Wayan, dkk. 2016. "Model Pembelajaran Role Playing Berbasis Pendekatan Saintifik Berpengaruh Terhadap Penguasaan Kompetensi Pengetahuan IPS". EJournal Mimbar PGSD Universitas Pendidikan Ganesha. Vol. 4, No. 1.

Ani, Ni Kd Kisri, dkk. 2017. "Pengaruh Model Pembelajaran Time Token Berbasis Tri Hita Karana Terhadap Hasil Belajar IPS Siswa Kelas V". E-Journal Mimbar PGSD Universitas Pendidikan Ganesha. Vol. 5, No. 2.

Apriliani, Ni K Winda, dkk. 2016. "Pendekatan Saintifik Berbantuan Media Gambar Berseri Berpengaruh Terhadap Keterampilan Menulis Siswa Kelas I SD”. E-Journal Mimbar PGSD Unibersitas Pendidikan Ganesha. Vol. 4, No. 1.

Ardiantari, Ni L. Pt. Novi, dkk. 2015. "Penerapan Pendekatan Saintifik dengan Penilaian Proyek untuk Meningkatkan Kemampuan Pemecahan Masalah dan Hasil Belajar Pengetahuan Matematika Tema Cita-Citaku Siswa Kelas IVB SD Negeri 8 Pemecutan". E-Journal Mimbar PGSD Universitas Pendidikan Ganesha. Vol. 3, No. 1.

Astianawan, I Pt, dkk. 2016. "Penerapan Pendekatan Saintifik Berbasis Penilaian Portofolio Dapat Meningkatkan Kemampuan Pemecahan Masalah Dan Penguasaan Kompetensi Pengetahuan Matematika Siswa Kelas III". E-Journal Mimbar PGSD Universitas Pendidikan Ganesha. Vol. 4, No. 1.

Dewi, Luh Pt Ariestia, dkk. 2015. "Penerapan Pendekatan Saintifik dengan Penilaian Proyek untuk Meningkatkan Kemampuan Berpikir Kreatif dan Hasil Belajar Pengetahuan Matematika Siswa Kelas IV SD". E-Journal Mimbar PGSD Universitas Pendidikan Ganesha. Vol. 3, No. 1.

Indrawan, I Wy Astra, dkk. 2017. "Pengaruh Model Pembelajaran Think Talk Write Berbasis Tri Hita Karana Terhadap Kompetensi Pengetahuan IPS". E-Journal Mimbar PGSD Universitas Pendidikan Ganesha. Vol. 5, No. 2. 
Megawati, Dewa Ayu Tri, dkk. 2015. "Penerapan Pendekatan Saintifik dengan Penilaian Proyek untuk Meningkatkan Kemampuan Penalaran dan Hasil Belajar Pengetahuan Matematika Siswa Kelas IVB SD". E-Journal Mimbar PGSD Universitas Pendidikan Ganesha. Vol. 3, No. 1.

Priyanti, Andrie Eka, dkk. 2016. "Pendekatan Saintifik Berbasis Problem Based Learning Berpengaruh Terhadap Hasil Belajar Pengetahuan Matematika Siswa Kelas IV SD Gugus P.B. Sudirman Denpasar Tahun Ajaran 2015/2016". E-Journal Mimbar PGSD Universitas Pendidikan Ganesha. Vol. 4, No. 1.

Putra, I G. N. Pt. A. Laksana, dkk. 2019. "Pengaruh Model SFAE Berorientasi Tri Hita Karana Terhadap Hasil Belajar IPA". E-Journal Mimbar PGSD Universitas Pendidikan Ganesha. Vol. 3, No. 2.

Putra, I Wayan Weda Gustana, dkk. 2016. "Pengaruh Model Pembelajaran SAVI Bermuatan Tri Hita Karana Terhadap Hasil Belajar IPA Siswa Kelas IV'. e-Journal Mimbar PGSD Universitas Pendidikan Ganesha.Vol. 4, No.1.

Setiawan, I Kd, dkk. 2016. "Penerapan Pendekatan Saintifik Berbasis Kearifan Lokal Untuk Meningkatkan Penguasaan Kompetensi Pengetahuan PKn Siswa Kelas VB SDN 1 Ubud Tahun Ajaran 2015/2016". E-Journal Mimbar PGSD Universitas Pendidikan Ganesha. Vol. 4, No. 1.

Susanto, Ahmad. 2013. Teori Belajar Dan Pembelajaran Di Sekolah Dasar. Jakarta: Kencana Prenada Media Group.

Sutoyo. 2011. Pendidikan Kewarganegaraan Untuk Perguruan Tinggi. Yogyakarta: Graha IImu.

Widariwati, N Putu, dkk. 2016. "Pendekatan Saintifik Berorientasi PBL Berpengaruh Terhadap Hasil Belajar Pengetahuan PKn Siswa Kelas V SD”. E-Journal Mimbar PGSD Universitas Pendidikan Ganesha. Vol. 4, No. 1. 